\title{
ELEMENTOS QUÍMICOS ESTRATÉGICOS PARA O BRASIL
}

Em todo o mundo, químicos promovem neste ano a divulgação da imagem que é, talvez, a mais representativa da ciência que os conquistou. Normalmente presente apenas em livros de química, em salas de aula e em imagens na web, desta vez a Tabela Periódica dos elementos químicos tornou-se definitivamente protagonista. Em formatos gigantes, ela é agora exposta em fachadas de instituições de ensino e pesquisa em diversos países, textos completos são divulgados em revistas científicas, simpósios e sessões especiais são organizados em eventos de toda natureza para reverenciar aquela que é, sem dúvida, a mais concisa e até então perfeita compilação de tudo que nos cerca. 2019 será sempre lembrado como a data em que o mundo comemorou o Ano Internacional da Tabela Periódica, em uma iniciativa da UNESCO para celebrar os 150 anos da primeira publicação da Tabela, organizada por Dmitri Ivanovich Mendeleiev, em 1869. Em um momento tão importante e delicado para a ciência mundial, promover e festejar a Tabela Periódica torna-se uma estratégia importante na luta para garantir o pensamento científico em todo o mundo, despertar vocações e assegurar o desenvolvimento econômico sustentável da humanidade.

Em 2019, a Sociedade Brasileira de Química capitaneou diversas ações para comemorar esse sesquicentenário. Dentre essas ações, a edição de um número especial da Química Nova que discorresse sobre elementos químicos estratégicos para o Brasil, e sobre o impacto científico, tecnológico e econômico que alguns elementos, em especial, têm para o país, pareceu-nos uma excelente oportunidade de envolver a comunidade química nacional e mostrar como tantos elementos deste Portal Químico são fundamentais para a soberania nacional.

Os textos, escritos por pesquisadores renomados das mais diversas áreas, cumpriram ainda com o objetivo de mostrar a importância da ciência brasileira e de seus cientistas para a exploração e valorização dessa riqueza única mundial. Além disso, despertar o interesse e inspirar jovens químicos para as oportunidades que esses elementos apresentam é uma missão importante destes autores que, em seus textos particularmente reflexivos, foram muito além da química à qual estamos habituados em nossa rotina acadêmica.

O número especial começa sua travessia com uma detalhada viagem no tempo, mostrando o longo e árduo caminho para a construção da Tabela Periódica tal qual a conhecemos hoje. Essa fascinante narrativa, feita por Filgueiras e colaboradores, começa com a descoberta dos primeiros elementos e vai até a ratificação dos nomes dos quatro mais novos elementos químicos que compõem a Tabela, ratificação esta realizada em julho de 2017, no Brasil, durante a realização do 46th Word Chemistry Congress-IUPAC, que ocorreu concomitantemente à $40^{\mathrm{a}}$ Reunião Anual da Sociedade Brasileira de Química, em São Paulo.

Em seguida, Ferro (Fe) e Cobre (Cu), os elementos metálicos que compõem os minérios mais importantes exportados pelo país, têm a sua química apresentada e suas potencialidades examinadas. Como a produção de aço está ligada à abundância de jazidas de ferro na natureza e como o aço é essencial para o desenvolvimento industrial de qualquer nação, o Professor Hélio Duarte discute, entre outras coisas, como esse elemento sempre ocupou um espaço extremamente importante na economia brasileira, impactando também os aspectos científicos, sociais e ambientais do país. Além de particularidades químicas e econômicas, Cunha e colaboradores apresentam, no seu texto sobre o cobre, informações importantes sobre a produção industrial e sobre o baixo beneficiamento do mineral ainda realizado por aqui (o que reflete em um longo caminho de industrialização a ser percorrido). Os autores também apresentam as valiosas aplicações em diferentes áreas deste que é um dos mais antigos elementos químicos descobertos e manipulados pelo homem, e que representa uma importante fonte de divisas para a nossa nação.

Alves e colaboradores apresentam uma visão científica bem atual do elemento Índio (In), presente em muitos dispositivos tecnológicos como nas telas de LCD, nas células fotovoltaicas e nos biossensores. Assim, pesquisas que utilizam o elemento e seus derivados com foco na ciência, tecnologia e inovação são importantes para a matriz de desenvolvimento brasileira, considerando que nosso país possui reservas potenciais dos minerais associados a ele.

A importância econômica do Manganês $(\mathrm{Mn})$ é reconhecida há tempos. Seu principal uso está associado à produção de aço. As reservas minerais e produção no Brasil são de elevada expressão no cenário internacional. Sua ocorrência geográfica se dá por quase todo o nosso território. O Professor Júlio Afonso apresenta novas perspectivas para o elemento, presente em fontes renováveis de energia (baterias de íon-lítio - $\mathrm{Li} / \mathrm{MnO}_{2}$ ), e projeta um aumento de sua importância estratégica para o futuro e para o país.

O Nióbio $(\mathrm{Nb})$ é um elemento bastante versátil, como bem assinalam Oliveira e colaboradores, podendo ser adicionado ao aço, melhorando suas propriedades como resistência, ou usado na fabricação de semicondutores. Óxidos de nióbio são empregados na fabricação de vidros especiais, películas de revestimento, em materiais bioativos ou capacitores cerâmicos. O Brasil destaca-se por possuir as maiores reservas existentes desse elemento no mundo, e isso aumenta nossa responsabilidade em adquirir conhecimento tecnológico para sua exploração e uso.

O Estanho (Sn) é apresentado pelo Professor Geraldo Lima como um metal importante na história e como elemento estratégico para o desenvolvimento do Brasil, devido às largas reservas de cassiterita presentes no nosso solo. Apontando as principais aplicações tecnológicas do metal, o autor defende fortemente o envolvimento de grupos brasileiros na química do estanho, para a descoberta de novos compostos, materiais e processos que agreguem valor ao mineral, já que a história do Brasil mostra que apenas exportar matéria-prima e insumos básicos não traz desenvolvimento.

O uso extensivo de fontes de energia não-renováveis tem impacto negativo sobre o meio ambiente. Assim, é fundamental o estabelecimento de uma Bioeconomia Verde em escala global, e a produção agrícola, base dessa bioeconomia, está fortemente apoiada no uso de fertilizantes, principalmente os macronutrientes da tríade NPK (nitrogênio, fósforo e potássio). O Brasil, como importante produtor agrícola, está entre os cinco maiores mercados de fertilizantes, daí a importância estratégica de tais elementos, como pontuam Galembeck e colaboradores.

Serra e colaboradores enfatizam que a importância dos 17 elementos químicos classificados como Terras Raras excede em muito os domínios científicos e tecnológicos, alcançando o mesmo nível de outros materiais estratégicos de energia e defesa. Historicamente detalham atividades extrativas desde o século 19 e apontam para perspectivas futuras relativas a este grupo de elementos no Brasil.

Finalmente, Zarbin e Orth optam por destacar, na química do elemento Carbono (C), quatro materiais estratégicos para o país, dois deles consolidados para a nossa economia (grafite e negro de fumo) e duas promessas com imenso impacto nos próximos anos (nanotubos de carbono e o grafeno). Em relação às duas últimas formas alotrópicas de carbono, com forte demanda mundial para aplicação em nanotecnologia, os autores ressaltam a alta competência de profissionais brasileiros na área e apontam investimentos públicos como essenciais para o Brasil se tornar competitivo na área. 
Em um país com enorme riqueza mineral e com um potencial tecnológico muito longe de ser explorado, esse número especial da Química Nova não teve o objetivo de cobrir todos os elementos estratégicos para o Brasil, presentes na Tabela, mas sim expor a opinião de importantes pesquisadores que aceitaram contribuir para influir a comunidade química na construção de um país cada vez mais desenvolvido econômica e tecnologicamente, usando a comemoração do Ano Internacional da Tabela Periódica como inspiração. Os editores desse número especial agradecem a cada um destes autores que, a despeito de um sem fim de atividades da carreira de pesquisadores/ professores, desprenderam uma energia considerável para escrever textos enriquecedores sobre elementos centrais para o nosso futuro.

Uma excelente leitura a todos.

Nelson H. Morgon

Universidade Estadual de Campinas, Campinas, Brasil Rossimiriam P. de Freitas ${ }^{(1)}$

Universidade Federal de Minas Gerais, Minas Gerais, Brasil Editores do Número Especial da Química Nova 